\title{
Rynki zbrojeniowe państw Unii Europejskiej: przykład Grecji i Polski
}

\section{Wprowadzenie}

W ostatnich latach następuje konsolidacja europejskiego potencjału zbrojeniowego. Przebiega ona zarówno dzięki nowym regulacjom prawnym i powołaniu odpowiedzialnych za ten proces instytucji (od lipca 2004 r. działa Europejska Agencja Obrony, zajmująca się standaryzacją sprzętu wojskowego) - jak i dzięki oddolnym decyzjom poszczególnych firm zbrojeniowych zacieśniających między sobą kooperację. Efektem są liczne interesujące programy zbrojeniowe i wzrost atrakcyjności europejskiego uzbrojenia w krajach trzecich. Jednak w II dekadzie XX wieku UE nadal jest mniej efektywnym eksporterem uzbrojenia niż USA i ten stan rzeczy prędko się nie zmieni. Powodem są wyższe wydatki badawczo-rozwojowe firm amerykańskich i większe zaawansowanie technologiczne amerykańskiego uzbrojenia. Dla eksportu swojej broni UE musi poszukiwać nowych rynków, bądź też stosować na kontrahentów presję polityczno-gospodarczą. W pierwszym rzędzie walczy o dominację na rynkach państw ze swojego bezpośredniego otoczenia, a w dalszej kolejności - o pozyskanie liczących się kontrahentów w innych częściach świata.

Naturalnymi nabywcami uzbrojenia produkowanego przez europejskie firmy zbrojeniowe są państwa europejskie. W niniejszym artykule zaprezentowane zostaną programy zbrojeniowe dwóch państw UE wydających na zbrojenia relatywnie duże środki - Grecji i Polski. Oba państwa starają się nabywać efektywne systemy uzbrojenia zarówno na rynku europejskim, jak i amerykańskim. Oba - wydając znaczne kwoty na obronność - starają się wyjść naprzeciw potencjalnym zagrożeniom, ponieważ w porównaniu z innymi członkami UE są bardziej narażone na konflikty militarne. Oba wreszcie w ostatnich latach borykały się z kryzysem gospodarczym (w Polsce przybrał on postać jedynie spowolnienia, w Grecji - głębokiej zapaści), który zmusił rządy do korekty planów zbrojeniowych.

\section{Grecja - ,armaty zamiast masła”}

Znaczącym nabywcą uzbrojenia na europejskim rynku jest Grecja. Trwająca od wielu dekad rywalizacja z Turcją (np. po secesji północnego Cypru w 1974 r.), a także aspiracje własnych elit politycznych, prowadziły do budowy potężnej - jak na greckie możliwości - armii. Ateny jeszcze przed kryzysem finansowym wydawały na wojsko rekordowe w skali Unii 4\% PKB, podczas gdy większość państw europejskich ma 
kłopoty z osiagnięciem zalecanego przez NATO minimalnego pułapu 2\% PKB (Polska w kolejnych budżetach rezerwuje środki nie mniejsze niż 1,95\%). Ewenementem w skali Europy okazała się jednak grecka gotowość do intensyfikacji zbrojeń - w obliczu głębokiego kryzysu finansowego, który ujawnił się na przełomie 2009 i 2010 r.

Jeszcze w 1999 r. Grecja zamówiła dużą partię samolotów wielozadaniowych „Eurofighter" produkowanych przez EADS i brytyjską korporację BAE Systems. Tych nowoczesnych maszyn ${ }^{1}$ Ateny zamówiły 90 , po 80 mln euro za każdą. Z kolei w $2000 \mathrm{r}$. Grecja zakontraktowała w koncernie Thyssen-Krupp cztery okręty podwodne klasy Edel 214, należące do najnowocześniejszych na świecie jednostek o napędzie konwencjonalnym (Wieliński, 2010). Okręty powstawały w stoczni w Kilonii, a kontrakt był wart 2 mld euro, jednak jego realizacja stanęła pod znakiem zapytania, gdy grecki kryzys finansowy spowodował zwłokę w płatności ostatniej transzy - $500 \mathrm{mln}$ euro. Sytuacja Grecji na przełomie 2009/2010 tak się pogorszyła, że aby uniknąć bankructwa, otrzymała ona 2 maja 2010 r. wsparcie w wysokości 110 mld euro od Unii Europejskiej i Międzynarodowego Funduszu Walutowego (MFW). Można było spodziewać się głębokich cięć w greckim budżecie obronnym, ale premier Jorgios Papandreu w październiku 2009 r. zadeklarował, że okręty zostaną opłacone i odebrane - wynegocjował jedynie redukcję ceny o $200 \mathrm{mln}$ euro. Pierwszy z nich („Papanikolis”) trafił do greckiej floty w 2010 r. Papandreu wprawdzie zredukował budżet obronny na 2010 r. aż o jedną czwarta, ale i tak wyniósł on 6,5 mld euro $^{2}$. Grecki budżet na zbrojenia na 2010 r. wynosił niemal 3\% PKB - większy odsetek na zbrojenia przeznaczają w NATO jedynie Stany Zjednoczone. Zresztą w porównaniu z cięciami w systemie socjalnym redukcje wojskowe są niewielkie - i tak w $2011 \mathrm{r}$. wydatki na zakup broni zredukowano o $460 \mathrm{mln}$ euro, ale planowano powetowanie ich w kolejnych latach - tymczasem wydatki socjalne zredukowano o 1,8 mld euro (Tatje, 2012).

Jako podstawową przesłankę takiej gotowości do zbrojeń greccy politycy podaja obawę Grecji przed Turcją i jej zbrojeniami: „Dopóki Turcja będzie prowadzić agresywną politykę, będziemy potrzebować środków, by się przed nią bronić” zadeklarował w kwietniu 2010 r. Philippos Petsalnikos, przewodniczący greckiego parlamentu (Wieliński, 2010). Z kolei Janis Emmanouilidis, ekspert brukselskiego European Policy Center stwierdził: „Strach przed Turcją jest elementem greckiej tożsamości. Wielu naszych polityków uważa, że kryzys kryzysem, ale armia musi być gotowa. Turcja to nadal nasz odwieczny wróg”. Emmanouilidis podsumował „Szalone zbrojenia skończą się, gdy Grecja wreszcie ułoży sobie stosunki z Turcją [...] Turcy wysłali dobry sygnał. Papandreu go podchwycił, bo chce pojednania. Ale na nie potrzeba czasu".

Oprócz okrętów podwodnych grecka armia zamówiła też za 2,5 mld euro sześć francusko-włoskich fregat typu FREMM. Z kolei dla wojsk lądowych w 2002 r. Grecy zakontraktowali w Niemczech 170 czołgów „Leopard II” za 1,8 mld euro - pojazdy dotarły do końca 2009 r. W 2010 r. Ateny zakupiły też w Niemczech ponad 200 samobieżnych haubic za 400 mln euro, a w niemiecko-francuskim koncernie EADS 20 helikopterów transportowych NH 90 (Grecja kupuje, 2012). Zakupy te przyczyniły się

1 Ich oblot nastapił w 1994 r., do produkcji seryjnej weszły w 2002 r.

2 PKB Grecji to ok. 190 mld euro, PKB Polski to ok. 500 mld euro (a nasze wydatki zbrojeniowe to rocznie ok. 30-35 mld zł, czyli 7,5-8,5 mld euro). 
w znacznej mierze do gwałtownego wzrostu greckiego zadłużenia. Jednym z niewielu skasowanych zamówień były „Eurofightery” z 1999 r. - w 2001 r. zredukowano ten kontrakt do 60 samolotów po $65 \mathrm{mln}$ euro, a następnie w ogóle anulowano.

Bardzo interesujące były oceny greckich zbrojeń w silniejszych państwach UE. Niemcy, których gospodarka wręcz na kryzysie skorzystała i które są największym eksporterem broni w Europie, nawet zachęcały Grecję do kolejnych zakupów uzbrojenia. W 2010 r. Grecy byli największym po Portugalczykach - notabene również znajdujących się na skraju bankructwa - odbiorcą niemieckiej broni (Bericht, 2010). Zachęty te stały w jaskrawej sprzeczności z formułowanymi przez tych samych niemieckich polityków i ekonomistów pod adresem Grecji zarzutami o niegospodarność i fałszowanie statystyk finansowych. Chęć zysku niemieckich przedsiębiorców była tak duża, że w lutym 2010 r. na Greków naciskał szef niemieckiej dyplomacji Guido Westerwelle, domagając się od nich zakupu „Eurofighterów”, a na przełomie kwietnia i maja 2010 r., w momencie negocjacji nad pakietem pomocowym dla Grecji, kanclerz Angela Merkel i francuski prezydent Nicolas Sarkozy mieli grozić, że zablokują pomoc, jeśli Ateny wycofają się z zakupu niemieckich U-Bootów i francuskich fregat. Rzecznik niemieckiego rządu z jednej strony chwalił grecki rząd za ,kroki zmierzające do konsolidacji budżetu”, z drugiej wyrażał nadzieję, że: „rząd grecki [...] weźmie pod uwagę redukcję wydatków w sektorze wojskowym", a wreszcie potępił przypadki nieuregulowania należności w kontraktach zbrojeniowych: „Rząd Niemiec dał wyraz swemu stanowczemu oczekiwaniu, że należy dotrzymywać zawartych umów” (Tatje, 2012).

Na przełomie 2011/2012 r. Grecji nadal groziło bankructwo, negocjowała kolejną transzę pomocy w wysokości 80 mld euro i desperacko cięła wszelkie wydatki publicz$\mathrm{ne}^{3}$. Redukcje przewidziane $\mathrm{w}$ programie oszczędnościowym nadzorowanym przez ekspertów MFW, Europejskiego Banku Centralnego i Komisji Europejskiej (KE) - tzw. „trójkę”, znów ominęły budżet na obronność i przemysł zbrojeniowy. Na kolejnym szczycie UE dnia 23 października 2011 r. A. Merkel i N. Sarkozy mieli ponownie naciskać na grecki rząd, aby wywiązał się z zawartych już kontraktów zbrojeniowych lub zawarł nowe (Tatje, 2012). W pozostałych państwach unijnych tylko nieliczni politycy domagali się publicznie redukcji greckich wydatków zbrojeniowych. Należał do nich Daniel Cohn-Bendit, lider Zielonych w Parlamencie Europejskim. Sygnały te nie miały jednak wielkiego znaczenia, podobnie jak sugestie KE z 2011, że Grecja powinna dążyć do ,zmniejszenia wydatków na obronność kraju”. W kolejnym budżecie, na 2012 r. przewidziano, że wydatki socjalne skurczą się o kolejne 2 mld euro (o 9\%), podczas gdy składka członkowska na rzecz NATO wzrośnie do $60 \mathrm{mln}$ euro (o 50\%), zaś bieżące wydatki obronne zwiększą się z 1,1 do 1,3 mld euro (o 18\%). Zapowiedziano wręcz, że po uzyskaniu kolejnej transzy pomocy międzynarodowej Grecja zakupi kolejną partię niemiecko-francuskiego uzbrojenia (Grecja kupuje, 2012).

Ochrona sektora zbrojeniowego przed redukcjami jest przez Greków akceptowana: przynajmniej jeden obszar rozbudowanej aktywności państwa zostaje utrzymany. Daje to Grekom poczucie bezpieczeństwa - oraz miejsca pracy, co ważne, gdyż Grecja prak-

3 W ateńskich szpitalach lekarze operowali jedynie w nagłych przypadkach, w szkołach brakowało podręczników, a liczni ekonomiści uznawali, że nie da się utrzymać Grecji w strefie euro i konieczne będzie przywrócenie drachmy. 
tycznie nie ma własnego przemysłu. Niemieckie przedsiębiorstwa zbrojeniowe wcześnie to dostrzegły i zadzierzgnęły silne więzi z greckimi partnerami.

Co interesujące, wydatki na zakup nowej broni nie były skorelowane z podnoszeniem, czy choćby utrzymaniem poziomu życia greckich żołnierzy. Ich wynagrodzenia od 2009 r. zredukowano nawet o 50\%, na początku 2013 r. szeregowy zarabiał netto 700, a porucznik 900 euro miesięcznie. Wydatki na uposażenia wojskowych zostały w Grecji zmniejszone w 2013 r. o niemal $80 \mathrm{mln}$ euro, a na 2014 r. zaplanowano kolejną redukcje - niemal o $90 \mathrm{mln}$ euro.

Według danych NATO, nawet w „najczarniejszych” latach 2012-2013, pomimo najgłębszego załamania w gospodarce i dochodach budżetowych, Grecy przeznaczali na obronę około 2,3\% PKB. W II połowie 2014 r., program modernizacji greckiej armii trwał w najlepsze (Palowski, 2014): planowano unowocześnienie posiadanego wyposażenia, w tym czterech morskich samolotów patrolowych P-3 „Orion” (350 mln euro), 4 fregat MEKO 200 (400 mln euro) oraz 36 wyrzutni MLRS M270. Do posiadanych czołgów „Leopard 2" planuje się zakup 30 tys. pocisków (za $150 \mathrm{mln}$ euro).

Były (do połowy 2011 r.) grecki szef dyplomacji Dimitris Droutsas podkreślał, że greckie granice trzeba chronić przed napływem imigrantów z Afryki Północnej i z Azji. Poza tym niemal codziennie dochodzić miało do granicznych incydentów z Turcją: „Gdy byłem ministrem spraw zagranicznych, każdego popołudnia otrzymywałem informację z ministerstwa obrony na temat przypadków naruszenia naszej przestrzeni powietrznej przez Turcję" (Tatje, 2012). Co więcej, Grecję niepokoiła wzrastająca aktywność tureckiej marynarki wojennej na Morzu Egejskim. To wytłumaczenie nie daje się do końca obronić: właśnie w 2011 r., gdy przez Morze Śródziemne ruszyła do Europy Południowej fala uchodźców z ogarniętej wojną domową Libii, okazało się, ze kraje najłatwiej dostępne z Afryki Północnej - Włochy i Grecja właśnie, na tyle ograniczyły swoje wydatki na ochronę granic morskich, że UE zmuszona była im pomóc, uruchamiając własne misje uszczelniające regiony Morza Śródziemnego. Europejska Agencja Zarządzania Współpracą Operacyjną na Granicach Zewnętrznych Państw Członkowskich Unii Europejskiej (FRONTEX) na wodach otaczających Włochy uruchomiła misję „Hermes 2011”, a wokół Grecji - „Posejdon 2011” (Wspólne, 2011).

Można przyjąć jako tezę dość prawdopodobną: maksymalizując zakupy uzbrojenia za granica, przy jednoczesnych cięciach wydatków na żołnierskie wynagrodzenia, czy też wydatków na ochronę granic do stopnia, w którym wkraczać muszą bezpośrednio agendy unijne, Grecja nie zwiększała swojego bezpieczeństwa. Można przyjąć, że zakupy te (dokonywane głównie w niemieckich i francuskich firmach) były swoistą „ceną" za pomoc finansową, udzielaną Grecji (również głównie z francuskich i niemieckich środków). W ten sposób niegospodarność i podatność na załamania gospodarcze zwiększały grackie uzależnienie nie tylko ekonomiczne - lecz także militarne - od silniejszych państw UE.

\section{Polska - ambitny program po korektach}

Jeszcze w 2001 r. wprowadzono w naszym prawie pewną ,kotwicę finansową” dla obronności, przyjmując że w każdorocznym budżecie wydatki na ten cel nie mogą 
spaść poniżej 1,95\% PKB. W ostatnich latach są to kwoty rzędu 30-35 mld zł, ale znaczną ich część pochłaniają koszty stałe: osobowe czy utrzymanie posiadanej infrastruktury i sprzętu. Na zakupy nowego wyposażenia pozostaje ok. 20\% budżetu - ok. 6,5 mld zł rocznie.

Na początku 2009 r. został zaprezentowany „Program Rozwoju Sił Zbrojnych” na lata 2009-2018. Przewidywano, że w tym okresie na modernizację techniczną będzie można przeznaczyć ok. 62 mld zł. Ponieważ kwota ta miała objąć też zakupy amunicji, serwisowanie i remontowanie sprzętu - realne środki na nowe wyposażenie miały wynosić ok. 50 mld zł. Przewidziane w planie projekty modernizacyjne można było podzielić na trzy grupy:

- kontynuacja czołowych programów wieloletnich, uruchomionych głównie w latach 2001-2003. Były to: Kołowy Transporter Opancerzony „Rosomak”, pociski przeciwpancerne „Spike”, pociski przeciwlotnicze „Grom” oraz pociski przeciwokrętowe RBS 15 Mk 3. Należało do nich doliczyć kontrakt na samoloty wielozadaniowe F-16, którego realizacja trwać miała do 2014 r. oraz pozyskanie samolotów C-130 „Hercules” od rządu USA w 2009 r.;

- projekty rozpoczęte tuż przed zatwierdzeniem programu oraz te, które dopiero miały wystartować. Były to: projekt indywidualnego wyposażenia i uzbrojenia żołnierza „Tytan”, zakupy nowych symulatorów i trenażerów, samolotu szkolno-bojowego, wdrażanie zmodernizowanych wyrzutni rakietowych WR-40 „Langusta”, ciężkich wyrzutni rakietowych MLRS „Homar” i dział samobieżnych kalibru 155 mm „Krab”, modernizacja (odziedziczonych jeszcze po Układzie Warszawskim) bojowych wozów piechoty BWP-1 oraz zakup samolotów M-28 „Skytruck”;

- najważniejsza grupa - pięć projektów określanych jako priorytety wieloletnie modernizacji technicznej armii na lata 2009-2018:

I. system obrony powietrznej: wojska przeciwlotnicze otrzymać miały zestawy artyleryjskie i artyleryjsko-rakietowe bliskiego zasiegu (odpowiednio do 4 i $10 \mathrm{~km}$ ) oraz zestawy rakietowe krótkiego i średniego zasięgu (odpowiednio do 25 i 100 km);

II. śmigłowce wsparcia bojowego i zabezpieczenia: wielozadaniowe, poszukiwawczo-ratownicze (serach and rescue, SAR) oraz przeznaczone do zwalczania okrętów podwodnych (ZOP) i zadań transportowych;

III. modernizacja Marynarki Wojennej: zakupy wielozadaniowych korwet „Gawron”, niszczycieli min „Kormoran”, okrętów podwodnych oraz uzbrojenia dla nadbrzeżnego dywizjonu rakietowego;

IV. systemy wsparcia dowodzenia oraz zobrazowania pola walki (C4ISR: Command, Control, Communications, Computers, Intelligence, Surveillance and Reconnaissance);

V. bezzałogowe statki latające (BSL, ang. UAV-unmanned aerial vehicle) rozpoznawcze i rozpoznawczo-uderzeniowe.

Zarówno kryzys ekonomiczny, jak i zmiana sytuacji międzynarodowej spowodowały konieczność odejścia od tego wieloletniego programu ${ }^{4}$. Jeszcze w 2010 r. zostało

4 W 2012 r. trzeba było w Stoczni Marynarki Wojennej w Gdyni przerwać prace nad korwetą „Gawron” - początkowo planowano budowę serii 7 jednostek, później program redukowano, aż pozostał kadłub tylko jednego okrętu. 
przyjętych 14 programów operacyjnych dotyczących modernizacji naszych sił zbrojnych, ale już w 2012 r. wymagały one modyfikacji i dopasowania do światowych trendów w zakresie nowych technologii militarnych (Skrzypczak, 2012, s. 26-31). Zbyt skromny był np. program BSL, który nie przewidywał wyposażenia naszej armii w różne ich typy (od rozpoznawczych po uderzeniowe) i dlatego można było go uznać za niepełny. Rozszerzenie programu modernizacji oznaczało jednak kolejne wydatki,

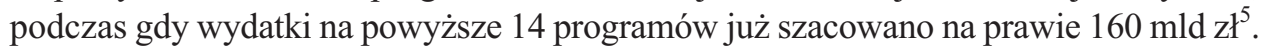
Kwota była gigantyczna, ale nieco bliższa realiom, jeśli program obejmowałby horyzont lat 2030-2040. Istotna byłaby też alokacja środków - rezygnacja z modernizacji starego, poradzieckiego sprzętu (wyrzutnie rakiet „Newa” czy czołgi T-72), który w ciagu kilku lat i tak straciłby walory bojowe. Środki te można było przeznaczać na nowe technologie.

Premier Donald Tusk w czasie swojego „drugiego exposé” 12 października 2012 r. zapowiedział, że w ciagu 2 lat MON dostanie $10 \mathrm{mld}$ zł na modernizację armii, a do 2022 r. na ten cel przeznaczy się 100 mld zł. Wydatki miałyby objąć zakupy dla sił zbrojnych, inwestycje w przemysł obronny i ośrodki naukowe. Dzięki produkcji w Polsce śmigłowców, okrętów, transporterów „Rosomak” czy przeciwrakietowego systemu obrony powietrznej miałyby powstawać nowe miejsca pracy. Warunkiem inwestycji w polski przemysł miała jednak być wysoka jakość sprzętu, jaki będą oferować nasze firmy. Premier podkreślił, że: „Bezpieczeństwo Polski możliwe jest też dzięki ścisłej współpracy z sojuszem i Stanami Zjednoczonymi w tworzeniu systemu obrony powietrznej, w tym przeciwrakietowej, a temu towarzyszy realizacja natowskiej idei smart defence".

Projekt modernizacji technicznej naszej armii przygotowywany był w sytuacji zmieniających się dla niej priorytetów. Nową hierarchię jej zadań postulował od $2012 \mathrm{r}$. prezydent Bronisław Komorowski, który najpierw przedstawił ,autorski” projekt polskiej tarczy antyrakietowej, a następnie wielokrotnie podkreślał, że aktywność zagraniczną i udział w misjach ekspedycyjnych polskich żołnierzy uważa za niewspółmiernie kosztowną w porównaniu $\mathrm{z}$ efektami i nazbyt obciążającą polskie siły zbrojne (Trudny, 2013, s. 8). Prezydent opowiedział się za strategią budowania polskiej armii pod kątem wzmacniania zdolności do obrony własnego terytorium oraz możliwości wypełnienia polskich zobowiązań wynikających z członkostwa w NATO.

Według przyjętego w grudniu 2012 r. przez Ministerstwo Obrony Narodowej „Programu rozwoju Sił Zbrojnych RP w latach 2013-2022" wydatki obronne w latach 2013-2016 wynieść miały ponad $135 \mathrm{mld}$ zł, w tym na modernizację techniczną - około 37,8 mld zł, czyli 27,8\% całości budżetu obronnego (Inwestycja, 2013, s. 9). Na lata 2017-2022 natomiast zapowiedziano wydatki obronne w wysokości 273 mld zł, z czego ponad 102 mld na modernizację techniczną. W ramach „Planu modernizacji technicznej Sił Zbrojnych RP na lata 2013-2022” opracowano kolejnych 14 priorytetów modernizacyjnych, wśród których znalazł się między innymi program obrony powietrznej i przeciwlotniczej. Resort obrony zaplanował też zakupy śmigłowców wsparcia bojowego i zabezpieczenia. W tym czasie armia dostałaby również 359 Ro-

5 Paradoksem było, że armia nie zawsze potrafiła należycie wykorzystać nawet tak skromne środki. W 2011 r. do Skarbu Państwa wróciło prawie 800 milionów złotych. 
somaków w wersji bojowej i 307 podwozi bazowych tych wozów pod wersje specjalne. Przewidziano także środki na rozwój Marynarki Wojennej (Siemoniak, 2013, s. $20-23)^{6}$.

Jesienią 2013 r. MON usystematyzował owe 14 priorytetów, a rząd przyjął je w dokumencie „Priorytetowe zadania modernizacji technicznej Sił Zbrojnych RP w ramach programów operacyjnych". Działo się to w momencie, gdy nasza gospodarka wyraźnie spowolniła wskutek światowego kryzysu, a wydatki na obronność po raz pierwszy zostały zredukowane poniżej 1,95\% PKB. Dokument, który został ujęty w projekcie budżetu na 2014 r., określał jakie są kluczowe programy operacyjne dla naszej armii i ustalał limit ich finansowania do 2022 r. Zakładano, że nasza armia do 2016 r. wyda na nowy sprzęt i uzbrojenie do 16 mld zł, a w latach 2014-2022 - ogółem 91,5 mld zł (było to znacznie mniej niż przewidywał „Program” z 2012 r.). Te redukcje miały być zrekompensowane przez dodatkowe wydatki na modernizację wojska nie uwzględnione w planie - ok. 40 mld zł, dzięki czemu łączne wydatki na modernizację armii nie skurczyłyby się zbytnio w porównaniu z „Programem” z 2012 r. (zmalałyby z ok. 140 do ok. 130 mld zł).

Zasada przeznaczania na bezpieczeństwo państwa przynajmniej 1,95\% PKB z roku poprzedniego została utrzymana, a pieniądze na programy modernizacyjne niewydane w danym roku budżetowym miały przechodzić na lata następne. Potencjalnym zagrożeniem na przyszłość był więc już nie brak środków, ale ich błędna alokacja czy nawet niemożność ich wykorzystania (w latach 2007-2011 nie wydano blisko 4 mld zł). Miała ona dwie przyczyny: błędnie zaplanowany w poprzednich latach program modernizacji technicznej i złe procedury zakupu sprzętu. Obowiązujące przepisy często wzajemnie się wykluczały, powodując chaos i utrudniając sprawne dostawy uzbrojenia.

Dla koordynacji i hierarchizacji szczegółowych projektów dotyczących przebudowy naszych sił zbrojnych rząd 17 września 2013 r. określił listę 14 priorytetowych programów na lata 2013-2022 (Uchwała, 2013). Pochłoną one w sumie 91 spośród 139 mld zł zaplanowanych na realizację planu w tym czasie i będą ujmowane w projektach ustaw budżetowych (Skrzypczak, 2012, s. 26-31) ${ }^{7}$.

Wśród priorytetów jest nie tylko modernizacja sił zbrojnych, ale też maksymalny, możliwy w niej udział krajowego przemysłu obronnego. Współudział, w wypadku rozwiązań pochodzących z zagranicy i optymalna ,polonizacja” powiązana z pozyskiwaniem nowoczesnych technologii. Program zakłada więc, że znaczna część z tej puli środków trafi do polskiego przemysłu, wzmacniając potencjał obronny i gospodarczy kraju.

Lista priorytetów według Ministerstwa Obrony Narodowej wygląda następująco:

1) system obrony powietrznej - w ramach programu będą pozyskiwane $m$.in. przeciwlotnicze zestawy rakietowe: średniego zasięgu ,Wisła”; krótkiego zasięgu „Narew”; samobieżne „Poprad”; przenośne „Grom” i „Piorun”; przeciwlotnicze systemy rakietowo-artyleryjskie bliskiego zasięgu „Pilica”; mobilne stacje radiolokacyjne „Soła” i „Bystra”;

${ }^{6}$ Nie wszystkie propozycje uwzględniono - zdaniem ministra obrony program modernizacji technicznej armii mógł zostać poszerzony o wprowadzenie nowego systemu kierowania i dowodzenia siłami zbrojnymi.

7 Pojawiały się tez kwoty wyraźnie wyższe, np. 160 mld zł. 
2) śmigłowce wsparcia bojowego, zabezpieczenia i VIP - w ramach programu będą pozyskiwane m.in. śmigłowce: wielozadaniowe, transportowe, poszukiwawczo-ratownicze (serach and rescue, SAR), zwalczania okrętów podwodnych, uderzeniowe, do przewozu pasażerów VIP;

3) zintegrowane systemy wsparcia dowodzenia oraz zobrazowania pola walki (C4ISR) - w ramach programu będą pozyskiwane m.in.: Zintegrowane Systemy Dowodzenia i Kierowania Środkami Walki, integrujące systemy rozpoznania, rażenia ogniowego i logistyki; Mobilne Moduły Stanowisk Dowodzenia; wozy dowodzenia i wozy dowódczo-bojowe oraz system monitorowania położenia wojsk własnych wyposażonych w transportery „Rosomak”; taktyczne systemy transmisji danych; systemy obrony przed cyberatakami;

4) modernizacja Wojsk Pancernych i Zmechanizowanych - unowocześnienie naszych czołgów „Leopard”. Prace potrwają do końca 2019 r., wartość kontraktu szacuje się na ok. miliard złotych, a unowocześnione maszyny otrzymają nową nazwę - Leopard 2PL;

5) zwalczanie zagrożeń na morzu - w ramach programu będą pozyskiwane m.in.: okręty podwodne nowego typu, niszczyciele min „Kormoran II”, okręty patrolowe: w wersji podstawowej „Ślązak” i z funkcją zwalczania min „Czapla”, okręty obrony wybrzeża „Miecznik”, okręt rozpoznania elektronicznego „Delfin”, okręt wsparcia działań połączonych „Marlin”, okręt ratowniczy „Ratownik”, pływająca stacja demagnetyzacyjna „Magneto”, nadbrzeżny dywizjon rakietowy Marynarki Wojennej i rakiety dla niego;

6) rozpoznanie obrazowe i satelitarne - w ramach programu będą pozyskiwane m.in. bezzałogowe statki powietrzne (BSP): krótkiego, średniego i operacyjnego zasięgu;

7) indywidualne wyposażenie i uzbrojenie żołnierza - w tym programie podstawą jest projekt ,Tytan”.

8) modernizacja Wojsk Rakietowych i Artylerii - w ramach programu pozyskiwane będą m.in.: armato-haubice $155 \mathrm{~mm}$ „Krab” wraz z inteligentną amunicją, wyrzutnie rakietowe „Homar”, samobieżne moździerze 120 mm „Rak”, Zautomatyzowany Zestaw Kierowania Ogniem „Topaz”, zestawy rozpoznania artyleryjskiego;

9) symulatory i trenażery;

10) samolot szkolno-treningowy;

11) samoloty transportowe - w ramach programu zostaną zakupione kolejne samoloty transportowe C-295M „Casa” oraz samoloty transportowe M-28 ,Skytruck” (Nowe, 2012, s. 11)

12) kołowe transportery opancerzone ROSOMAK ${ }^{9}$ - budowa ok. 700 transporterów „Rosomak” (zarówno w wersjach bojowych, jak i specjalistycznych);

8 Jeszcze w 2012 r. zawarto umowę na zakup pięciu kolejnych maszyn CASA C-295M, o wartości ok. $900 \mathrm{mln}$ zł (wraz z pakietem logistycznym i offsetem obejmującym zorganizowanie w Polsce centrum serwisowego dla tych maszyn). Po dostarczeniu tej partii samolotów, Polska posiada ich razem 16 i jest jednym z większych użytkowników na świecie. Stacjonują one w 8 Bazie Lotnictwa Transportowego w Krakowie.

9 Do 2018 r. Wojskowe Zakłady Mechaniczne w Siemianowicach Śląskich wyprodukują kolejnych 200 „Rosomaków”, a ogólna liczba maszyn przekazanych naszej armii wzrośnie do około 850 sztuk. 


\section{3) przeciwpancerne pociski kierowane SPIKE;}

14) rozpoznanie - w ramach tego programu będą pozyskiwane m.in.: lekkie opancerzone transportery rozpoznawcze, pojazdy rozpoznawcze dla pododdziałów dalekiego rozpoznania, mobilne bezzałogowe pojazdy rozpoznawcze, informatyczny system zbierania, analizy i dystrybucji informacji, zautomatyzowany system zbierania, gromadzenia, przetwarzania i dystrybucji.

Modernizacja polskiej armii to zadanie długofalowe, na szczęście poważne kroki już podjęto i stan naszych sił zbrojnych powinien z każdym rokiem się poprawiać. Jest to szczególnie ważne z uwagi na konflikt ukraińsko-rosyjski, który destabilizuje Europę Wschodnią i niesie ze sobą potencjalne zagrożenia również dla Polski. Rozmaite formy nieoficjalnej agresji, nasyłanie bojówkarzy i regularnej armii udających ,separatystów" w poszczególnych regionach - stały się w ciagu ostatniego roku rzeczywistością i w dodatku dość skutecznym narzędziem realizacji mocarstwowych aspiracji Rosji. O ile trudno oczekiwać, aby polska armia potrafiła o własnych siłach wygrać wojskową konfrontację z Rosją - o tyle można ją doposażyć na tyle, aby walczyła lepiej niż siły ukraińskie, a zwłaszcza - aby mogła powstrzymać agresję do czasu otrzymania pomocy od zachodnioeuropejskich sojuszników.

\section{Podsumowanie}

Podstawową różnicą między koncepcjami obronnymi Polski i Grecji jest inaczej zdefiniowane zagrożenie. Podstawowym zagrożeniem dla Polski jest Rosja, przy czym agresja z jej strony może przybrać rozmaite formy: kombinowanej presji ekonomiczno-dywersyjnej (wojna elektroniczna), ograniczonej agresji w postaci podsycania separatyzmów (czy wręcz kreowania ich na potrzeby konfliktu), a wreszcie - otwartego ataku z Kaliningradu czy też przez Białoruś (w niektórych scenariuszach Rosjanie zakładają nawet zastosowanie wobec Polski broni masowego rażenia). W innych wariantach Polska nie byłaby atakowana bezpośrednio, ale musiałaby wspierać słabszych sojuszników w ramach NATO (np. państwa nadbałtyckie) w ich konflikcie z Rosją. Ewentualne starcie miałoby charakter przede wszystkim lądowy z silnym komponentem powietrznym i drugorzędnym - morskim.

Podstawowym zagrożeniem państwowym dla Grecji jest Turcja - państwo będące również członkiem NATO, nieposiadające broni masowego rażenia, w związku z tym w swoich zachowaniach bardziej przewidywalne. Ewentualne starcie miałoby przede wszystkim charakter morski, z uzupełniającymi go walkami o panowanie w powietrzu, duże starcia na lądzie (wyspy Morza Egejskiego czy krótka granica lądowa) byłyby mniej prawdopodobne. Podobnie jak Polska, Grecja może zostać uwikłana w konflikt nie bezpośrednio (np. w związku z sytuacją na Cyprze). Grecja stoi natomiast wobec innego typu zagrożeń, których nie musi obawiać się Polska - masowej, niekontrolowanej imigracji ludności muzułmańskiej z Bliskiego Wschodu lub przez Morze Śródziemne, a w związku z tym - pojawienia się na greckim terytorium grup radykałów muzułmańskich czy wręcz terrorystów.

Interesująca - i korzystna dla Polski - jest proporcja wydatków obronnych do kondycji własnego przemysłu zbrojeniowego. Grecja wydaje na obronność większy ułamek 
swojego PKB niż Polska - ale w zasadzie całe nowoczesne uzbrojenie musi importować, co czyni ją bardzo zależną politycznie i gospodarczo od kontrahentów wojskowych. Polska ma znaczący sektor przemysłu obronnego i znaczna część składanych przez nas zamówień zagranicznych zawiera opcję ,,polonizacji” - wejścia przez sprzedawcę do kooperacji z naszymi firmami, dostarczenie im „offsetu”. O ile Grecja otrzymuje sprzęt ,pod klucz”, o tyle Polska może pozwolić sobie na modernizację kupowanego sprzętu we własnych fabrykach - doskonałym przykładem są tu transportery „Rosomak”.

Rozbieżne strategie zaopatrzenia w broń Polski i Grecji wykazują, że w Europie jeszcze długo nie powstanie wspólny rynek uzbrojenia, a działania agend takich jak Europejska Agencja Obrony będą ograniczały się do ułatwiania kontrahentom poszukiwania na wspólnym rynku sprzętu odpowiadającego ich narodowym - i często nader rozbieżnym - zapotrzebowaniom.

\section{Bibliografia}

Bericht der Bundesregierung über ihre Exportpolitik für konventionelle Rüstungsgüter im Jahre 2010 (Rüstungsexportbericht 2010), http://www.sipri.org/research/armaments/transfers/transparency/national_reports/germany/germny-2010.pdf, 10.09.2014.

Grecja kupuje niemiecka broń za fundusze z pakietów pomocowych, 10.01.2012, „Gazeta Wyborcza”, http://m.wyborcza.biz/biznes/1,106501,10941152,Grecja_kupuje_niemiecka_bron_za_fundusze_z_pakietow.html, 10.09.2014.

http://www.defence24.pl/news_mon-priorytety-modernizacji-sil-zbrojnych, 19.10.2013.

Inwestycja w armię, „Polska Zbrojna” ze stycznia 2013 r.

Nowe skrzydta, ,Polska Zbrojna” z sierpnia 2012 r.

Palowski J. (2014), Grecja modernizuje uzbrojenie za miliard euro, 21.07.2014, http://www.defence24.pl/news_grecja-modernizuje-uzbrojenie-za-miliard-euro, 15.09.2014.

Siemoniak T. (2013), O wojsku bez przesqdów, „Polska Zbrojna” z lutego 2013 r.

Skrzypczak W. (2012), Punkty krytyczne, „Polska Zbrojna” z czerwca 2012 r.

Tatje C. (2012), Grecka armia nie wie, co to oszczędności, 11.01.2012, „Die Zeit Hamburg”, http://www.voxeurop.eu/pl/content/article/1383861-grecka-armia-nie-wie-co-oszczednosci, 10.09.2014.

Trudny, ale dobry rok, „Polska Zbrojna” z kwietnia 2013 r.

Uchwała Rady Ministrów nr 164 z dnia 17 września 2013 r. w sprawie ustanowienia programu wieloletniego „Priorytetowe Zadania Modernizacji Technicznej Sit Zbrojnych Rzeczypospolitej Polskiej w ramach programów operacyjnych", Monitor Polski, Dziennik Urzędowy Rzeczypospolitej Polskiej, Warszawa, dnia 4 października 2013 r., poz. 796.

Wieliński B. (2010), Grecja kupuje broń za 2 mld euro, 21.05.2010, „Gazeta Wyborcza”, http://wyborcza.pl/1,76842,7912979,Grecja_kupuje_bron_za_2_mld_euro.html\#ixzz3CSybwfsD, 10.09.2014.

Wspólne podejście do migracji z Afryki Pólnocnej, 15.04.2011, http://consilium.europa.eu/homepage/ showfocus?focusName=jointly-managing-migration-from-north-africa\&lang=pl, 30.08.2014. 


\section{Streszczenie}

Unia Europejska od dekady podejmuje działania na rzecz konsolidacji rynków zbrojeniowych. Jednak istotną przeszkodą w tym procesie są zróżnicowane interesy, strategie bezpieczeństwa i możliwości poszczególnych państw członkowskich. Polska i Grecja są nielicznymi członkami UE, którzy w ostatnich latach zwiększają swoje wydatki obronne. Oba kraje jednak w swoich zakupach zbrojeniowych kierują się innymi celami. Polska obawia się lądowego starcia z przeciwnikiem posiadającym broń masowego rażenia i demonstrującym lekceważenie dla norm prawa międzynarodowego. Natomiast dla Grecji potencjalnym przeciwnikiem jest członek tego samego sojuszu wojskowego, bardziej przewidywalny w swoich zachowaniach, a ewentualne starcie miałoby charakter powietrzno-morski. Grecja natomiast bardziej niż Polska narażona jest na ataki terrorystyczne i niekontrolowane migracje. Polska posiada liczący się przemysł zbrojeniowy i część zapotrzebowania wojskowego może wyprodukować o własnych siłach. Grecja jest zmuszona do importowania o wiele większej ilości broni. Trudno więc liczyć na standaryzację uzbrojenia na europejskich rynkach czy też na znaczące zbliżanie strategii bezpieczeństwa rozmaitych członków UE.

Słowa kluczowe: Unia Europejska, bezpieczeństwo międzynarodowe, zbrojenia, budżet

\section{EU arms markets in Greece and Poland}

\section{Summary}

The European Union has been acting to consolidate arms markets for a decade. These endeavours have been seriously impeded by the diverse interests, security strategies and potential of individual member states. Poland and Greece are among the few EU members that have been increasing their defence expenditure in recent years. They are driven by different objectives when making their arms purchases, though. Poland fears a land confrontation with an enemy possessing weapons of mass destruction and demonstrating disregard for the norms of international law. Greece, in turn, sees a potential enemy in a member of the same military alliance, whose behaviour is more predictable, and where the potential confrontation would occur in the air and at sea. Greece is also at a greater risk of terrorist attacks and uncontrolled immigration than Poland. Poland has a considerable arms industry and is able to produce a part of its military supplies on its own. Greece is required to import weapons to a much greater extent. It is therefore difficult to assume the standardisation of weapons in European markets or any considerable convergence of security strategies implemented by different EU members.

Key words: European Union, international security, armament, budget 
